\title{
MENINGKATKAN MUTU PENDIDIKAN ATAU MENJAMIN MUTU PENDIDIKAN MELALUI SUPERVISI PENDIDIKAN UNTUK MENCAPAI KUALITAS PENDIDIKAN NASIONAL
}

\author{
Oleh : Windi Astuti \\ Gmail : windiastuti2206@gmail.com
}

\begin{abstract}
ABSTRAK
Banyak sekali faktor yang menjadikan rendahnya kualitas pendidikan di Indonesia. Faktor-faktor yang bersifat te knis diantaranya adalah rendahnya kualitas guru, rendahnya sarana fisik, mahalnya biaya pendidikan, rendahnya pres tasi sis wa, rendahnya kese jahte raan guru, rendahnya re levansi pendidikan dengan kebutuhan, kurangnya pemerataan kesempatan pendidikan. Namun sebenamya yang menjadi masalah mendasar dari pendidikan di Indonesia adalah sistem pendidikan di Indones ia itu se ndiri yang menjadikan sis wa se bagai objek, sehingga manusia yang dihasilkan dari sistem ini adalah manusia yang hanya siap untuk memenuhi kebutuhan zaman dan bukannya bersikap kritis te rhadap zamannya. Maka disinilah dibutuhkan ke rja sama antara pe me rintah dan mesyarakat untuk mengatasi se gala pe rmasalahan pendidikan di Indonesia. supervisi mempunyai tujuan yang jelas dan sangat baik yaitu membimbing dan membantu kesulitan para guru dalam mengarajar dan belajar agar dapat tercapainya tujuan pembelajaran yang efektif dan efisien pada khusunya dan peningkatan kualitas mutu pendidikan pada umumnya. Dan dalam pelaksanan supervisi maka harus berpengang te guh pada prinsip-prinsip yang sudah ditentukan. Supervisiyang dilakukan oleh kepala sekolah sebaiknya tidak hanya kepada para guru saja, namu hendak nya ke pada seluruh elemen se kolah yang dise rtai tugas -tugas tertentu se perti bagian, administrasitata usaha, perpus takaan, laboratorium, ekstra kurikuler dan bagian tugas lainnya. Sehingga dalam kenyataannya supervisi tidak hanya dijadikan se suatu aktifitas kelengkapan atau pe nye mpurnaan struktural oraganis asi sekolah
\end{abstract}

\section{PENDAHULUAN}

\section{A. Latar Belakang}

Pendidikan Indonesia ini masih jauh dari kata layak. Di segala segi faktor yang dibahas masih banyak masalah yang harus ditangani. Kualitas pendidikan masih sulit sekali ditingkatkan. Oleh karena itu kita perlu membangun kembali pondasi pola berpikir kita meningkatkan kesadaran akan pentingnya pendidikan, masyarakat sekitar pun harus turut mendukung. Meningkatkan kualitas pendidikan dengan cara kita mengetahui terlebih dahulu apa pentingnya pendidikan dan mempunyai kesadaran yang tinggi dan turut berpatisipasi dalam meningkatkan pendidikan. Generasi muda tugasnya berat karena harus menjadi penerus bangsa yang beradab. 
Sebagai kegiatan pengawasan yang mengacu pada unsur pembinaan, supervisi pendidikan yang ada saat ini belum sesuai harapan. Menurut Susi Anto, pembinaan atas hasil supervisi tersebut bisa berupa bimbingan atau tuntunan ke arah perbaikan situasi pendidikan pada umumnya dan peningkatan mutu mengajar dan belajar pada khususnya. Namun ternyata dari berbagai hasil penelitian, pengamatan dan pengalaman, supervisi pendidikan belum mencapai tujuan tersebut.

\section{B. Rumus an Masalah}

1. Bagaimana kondisi pendidikan di Indonesia yang seharusnya?

2. Bagaimana kondisi supervisi pendidikan di Indonesia saat ini?

\section{Tujuan}

sebagai bahan masukan bagi supervisor dalam rangka memberikan atau mengadakan perbaikan dikemudian hari. Dengan demikian kelak supervisor benar-benar membantu usaha sekolah secara menyeluruh guna peningkatan pendidikan di Indonesia.

\section{PEMBAHASAN}

Pendidikan di Indonesia sampai saat ini belum jelas akan ke mana arahnya, belum bisa merata antara daerah satu dan daerah yang lain. Pemerintah sampai saat ini masih mengalami kebingungan apa yang akan mereka harapkan dan mereka pakai untuk menuju masyarakat pembelajar di negeri ini. Sehingga, banyak nilai pelajaran yang diambil dari luar atau diadopsi dari negera-negara yang sudah maju. Meskipun ada sisi positifnya, namun juga tidak boleh dikesampingkan sisi negatif dari pengadopsian kurikulum dari negara lain. Pihak sekolah, pemerintah, dan masyarakat bahu-membahu dalam upaya mengembangkan bangsa melalui jalur pendidikan. Karena, tanpa adanya saling bekerjasama tidak mungkin semua akan tercapai dengan baik. Sebagai harapan nilai-nilai religi harus selalu sebagai landasan bagi semua pihak dalam melaksanakan roda pendidikan ini. Semoga bangsa ini segera sembuh dari keterpurukan dan pembodohan yang tersistematis.

Dari sudut pandang manajemen SDM guru, guru masih berada dalam pengelolaan yang lebih bersifat birokratis-administratif yang kurang berlandaskan paradigma pendidikan (antara lain manajemen pemerintahan, kekuasaan, politik, dsb.). Dari aspek unsur dan prosesnya, masih dirasakan terdapat kekurang-terpaduan antara sistem pendidikan, rekrutmen, pengangkatan, penempatan, supervisi, dan pembinaan guru. Masih dirasakan belum terdapat keseimbangan dan kesinambungan antara kebutuhan dan pengadaan guru. Rerkrutmen dan pengangkatan guru masih selalu diliputi berbagai masalah dan kendala terutama dilihat dari aspek kebutuhan kuantitas, kualitas, dan distribusi. Pelaksanaan otonomi daerah yang "kebablasan" cenderung membuat manajemen guru menjadi makin semrawut. Pembinaan dan supervisi dalam jabatan guru belum mendukung terwujudnya pengembangan pribadi dan profesi guru secara proporsional Dengan demikian guru sangat perlu untuk disupervisi untuk mengantar mereka memasuki suasana kerja yang selalu berubah dan diperbarui. Dengan memperoleh supervisi, guru-guru tersebut dapat menyesuaikan diri dengan situasi barunya. Semua situasi tersebut di atas memerlukan adanya pelaksanaan program supervisi pendidikan yang mantap dan terarah. Untuk melaksanakan program supervisi pendidikan yang mantap perlu adanya evaluasi yang baik, yaitu dengan berpegang teguh kepada prinsip-prinsip obyektif, kooperatif, integral, dan kontinue. ${ }^{1}$ 


\section{PENUTUP}

\section{Kesimpulan}

Banyak sekali faktor yang menjadikan rendahnya kualitas pendidikan di Indonesia. Faktor-faktor yang bersifat teknis diantaranya adalah rendahnya kualitas guru, rendahnya sarana fisik, mahalnya biaya pendidikan, rendahnya prestasi siswa, rendahnya kesejahteraan guru, rendahnya relevansi pendidikan dengan kebutuhan, kurangnya pemerataan kesempatan pendidikan. Namun sebenarnya yang menjadi masalah mendasar dari pendidikan di Indonesia adalah sistem pendidikan di Indonesia itu sendiri yang menjadikan siswa sebagai objek, sehingga manusia yang dihasilkan dari sistem ini adalah manusia yang hanya siap untuk memenuhi kebutuhan zaman dan bukannya bersikap kritis terhadap zamannya. Maka disinilah dibutuhkan kerja sama antara pemerintah dan mesyarakat untuk mengatasi segala permasalahan pendidikan di Indonesia. supervisi mempunyai tujuan yang jelas dan sangat baik yaitu membimbing dan membantu kesulitan para guru dalam mengarajar dan belajar agar dapat tercapainya tujuan pembelajaran yang efektif dan efisien pada khusunya dan peningkatan kualitas mutu pendidikan pada umumnya. Dan dalam pelaksanan supervisi maka harus berpengang teguh pada prinsip-prinsip yang sudah ditentukan.

Supervisi yang dilakukan oleh kepala sekolah sebaiknya tidak hanya kepada para guru saja, namu hendaknya kepada seluruh elemen sekolah yang disertai tugas-tugas tertentu seperti bagian, administrasi tata usaha, perpustakaan, laboratorium, ekstra kurikuler dan bagian tugas lainnya. Sehingga dalam kenyataannya supervisi tidak hanya dijadikan sesuatu aktifitas kelengkapan atau penyempurnaan struktural oraganisasi sekolah.

\section{Saran}

Perkembangan dunia di era globalisasi ini memang banyak menuntut perubahan kesistem pendidikan nasional yang lebih baik serta mampu bersaing secara sehat dalam segala bidang. Salah satu cara yang harus di lakukan bangsa Indonesia agar tidak semakin ketinggalan dengan negara-negara lain adalah dengan meningkatkan kualitas pendidikannya terlebih dahulu. Dengan meningkatnya kualitas pendidikan berarti sumber daya manusia yang terlahir akan semakin baik mutunya dan akan mampu membawa bangsa ini bersaing secara sehat dalam segala bidang di dunia internasional.

\section{DAFTAR PUSTAKA}

sabandi, A. (2013). Supervisi Pendidikan Untuk Pengembangan Profesionalitas Guru Berkelanjutan.

Pedagogi jurnal ilmiah ilmu pendidikan , XIII (2), 1-9.

Tarbiyah MF, Uin K, Makassar A, No SA, Email SG. SISTEM PENDIDIKAN DI INDONESIA: antara keinginan dan realita. 2015;2(2):233-245. https://www.scribd.com/document/399099664/8791650-1-SM-pdf. 